\title{
A note on network structure: functional relationships between network indicators
}

Citation for published version (APA):

van Wegberg, M. J. (2003). A note on network structure: functional relationships between network indicators. METEOR, Maastricht University School of Business and Economics. METEOR Research Memorandum No. 032 https://doi.org/10.26481/umamet.2003032

Document status and date:

Published: 01/01/2003

DOI:

10.26481/umamet.2003032

Document Version:

Publisher's PDF, also known as Version of record

\section{Please check the document version of this publication:}

- A submitted manuscript is the version of the article upon submission and before peer-review. There can be important differences between the submitted version and the official published version of record.

People interested in the research are advised to contact the author for the final version of the publication, or visit the DOI to the publisher's website.

- The final author version and the galley proof are versions of the publication after peer review.

- The final published version features the final layout of the paper including the volume, issue and page numbers.

Link to publication

\footnotetext{
General rights rights.

- You may freely distribute the URL identifying the publication in the public portal. please follow below link for the End User Agreement:

www.umlib.nl/taverne-license

Take down policy

If you believe that this document breaches copyright please contact us at:

repository@maastrichtuniversity.nl

providing details and we will investigate your claim.
}

Copyright and moral rights for the publications made accessible in the public portal are retained by the authors and/or other copyright owners and it is a condition of accessing publications that users recognise and abide by the legal requirements associated with these

- Users may download and print one copy of any publication from the public portal for the purpose of private study or research.

- You may not further distribute the material or use it for any profit-making activity or commercial gain

If the publication is distributed under the terms of Article $25 \mathrm{fa}$ of the Dutch Copyright Act, indicated by the "Taverne" license above, 


\title{
A note on network structure: functional relationships between network
}

\section{indicators}

Marc van Wegberg

June 2003

\begin{abstract}
Two important aspects of network structure are network density and network centrality. These two aspects highlight different characteristics of a network. Empirical studies tend to find that one or the other is the better explanatory variable for certain aspects of corporate behaviour. This note makes a simple and compelling point. There is a hill-shaped relationship between network density and network centrality. A purely stochastic process of alliance formation will lead to a hill-shaped relationship. A mathematical, functional relationship can be shown between network density and the upper bound to network centrality. The combination of these outcomes sets lower and upper bounds on network centrality. This approach can offer a vantage point for an evolutionary study of network structure.
\end{abstract}

Assistant Professor, Department of Organization \& Strategy, Faculty of Economics and Business Administration, University of Maastricht, P.O. Box 616, 6200 MD Maastricht, The Netherlands, tel. +31 43-3883654, fax. +31 43-3884877, e-mail: m.vanwegberg@os.unimaas.nl, mvanwegberg@yahoo.com, home page: http://www.geocities.com/mvanwegberg/. I thank Martin Carree and Arjen van Witteloostuijn for their extensive comments on the paper. 


\section{Introduction}

Alliances and interlocking directorates are examples of links (or ties) between companies. The ensemble of links constitutes a social network of the companies involved. Social networks act as conduits of information. The structure of a social network determines who has access to information and under which conditions. The network structure describes features of the network that are measurable, stable, and that capture the influence of the network on information flows and resulting firm behavior. Among several indicators of network structure, two stand out. Network density indicates how many of the possible links between firms are actually formed. A dense network will tend to quickly spread information. News of unethical or opportunistic behavior tends to travel fast in a dense network. A dense network provides a control benefit that reduces unethical behavior and increases trust (Brass, Butterfield, \& Skaggs, 1998; Hite \& Hesterly, 2001). A dense network may also reduce the ability of individual network members to manipulate and control others (Burt, 1997). Network centrality indicates how much firms differ in the extent of being linked to others in the network. Someone with a central and unique position in a network tends to benefit from that (Burt, 1997; Kogut, Walker, \& Kim, 1995; Powell, Koput, \& Smith-Doerr, 1996). Network centrality can indicate network power (social capital): a betterconnected firm has an information advantage, which it may use to control other firms that have less access to information. Since it leads to information asymmetry, network centrality predicts strategic advantages and potential performance benefits for firms that occupy central positions in the network.

Firms create alliances and other links with each other in order to improve their information access. They may also be motivated by an attempt to increase their overall network position. The creation of new links changes both the density of the network and its centrality. Both network density and network centrality are functions of the number and allocation of links between nodes in the network. They are thereby interrelated, which accounts for a functional relation between them. An important relationshp between network density and centrality is that the higher the density of a network, the higher network centrality is, up to a point, beyond which centrality decreases. When the number of network links increases, some firms initially may attract more links than others. As a result of this difference in connectedness, the network becomes somewhat centralized. If the number of links increases still further, the less well connected firms catch up with the others. As a result, network centrality decreases again. This relationship is implicit in the seminal article by Kogut, Walker and Kim (1995). Network centrality is zero in both extreme cases where there are no links and where every firm is linked to every other one (Kogut et al., 1995). When density lies in between these extreme cases, we can expect a positive level of network centrality. This argument leads to the following proposition:

\section{There is a hill-shaped relationship between network density and network centrality, with network centrality peaking for intermediate levels of network density.}

For given levels of network density, we will develop the lower bound and the upper bound of network centrality. The lower bound is based on stochastic effects, resulting from chance elements in link formation. This approach is similar to Sutton's (1997) theory of lower bounds on concentration, based on independence effects. While rivals are interdependent as they compete in a market, they also face independent growth opportunities. The chance that a firm realizes a growth opportunity has an effect on the overall size distribution of firms in a market. This process sets a lower bound on concentration. Alliances too express to some extent local and independent opportunities. The chance element of realizing this opportunity sets a lower bound on network centralization. The upper bound on network centrality depends directly on network density: given the number of links, there is a maximum to the centrality that a network can achieve. 


\section{Network structure}

We begin with definitions of network structure. The simplest element of network structure is network size, that is, the number of network members, the population N (Burt, 1997). The second element of network structure is network density. Call $\mathrm{L}_{\mathrm{i}}$ the actual number of firms that an individual firm $i$ is linked to. In a network of $\mathrm{N}$ firms, each firm can form $\mathrm{N}-1$ possible links. Network density is the relative measure of which possible links are actually formed (Burt, 1997; Kogut et al., 1995). One firm may form $\mathrm{N}-1$ links. For $\mathrm{N}$ firms this gives $\mathrm{N}(\mathrm{N}-1)$ possible links. Network density D is the total number of links that have been formed, divided by the total number of possible links. This is a number between 0 and 1 defined as follows:

$$
\mathrm{D}=\frac{\sum_{i=1}^{N} L_{i}}{N(N-1)}
$$

Network centrality indicates the extent to which some firms are more central in the network than others. There are several different statistics for network centrality, largely based on work by Linton Freeman (Kogut et al., 1995; Madhavan, Koka, \& Prescott, 1998; Powell et al., 1996). The most basic indicator is the degree centrality (Bonaccorsi \& Giuri, 2001; Powell et al., 1996). The degree centrality of an individual firm indicates how intensely it is connected to the network. It is normalized as a number between 0 and $1: \mathrm{C}_{\mathrm{i}}=\frac{L_{i}}{N-1}$. The most central firm is the one with the highest degree centrality, $\mathrm{C}_{\mathrm{dmax}}=\mathrm{L}_{\max } /(\mathrm{N}-1)$. The degree centrality of the network, $C_{d}$, is the average distance between the degree centrality of the most central firm and every other firm. Dividing this expression by $\mathrm{N}-2$ normalizes the degree centrality between 0 and 1 :

$$
C_{d}=\frac{1}{(N-2)} \sum_{i=1}^{N}\left(C_{d \max }-C_{i}\right)
$$

The betweenness centrality indicator also goes back to Linton Freeman (Kogut et al., 1995; Madhavan et al., 1998). Betweenness measures for each firm $k$ how many pairs of firms $\mathrm{i}$ and $\mathrm{j}$ firm $\mathrm{k}$ connects (i.e., $\mathrm{i}$ and $\mathrm{j}$ are both connected to $\mathrm{k}$ ), and how important this connection is for the pair $\mathrm{i}$ and $\mathrm{j}$ (which share this connection is among all direct and indirect contacts between $\mathrm{i}$ and $\mathrm{j}$ ). If firm $i$ and $j$ have a direct connection, then $a(i, j)=1$, otherwise, $a(i, j)=0$. The betweenness centrality of an individual firm $k$ to $a$ pair of firms $i, j, C_{k}(i, j)$, equals $\frac{a(i, k)^{*} a(k, j)}{a(i, j)+\sum_{h \neq i, j} a(i, h)^{*} a(h, j)}$. The highest value of this indicator $\mathrm{C}_{\mathrm{k}}(\mathrm{i}, \mathrm{j})$ is 1 , when firm $\mathrm{k}$ is the one link between firms $\mathrm{i}$ and $\mathrm{j}$. Firm $\mathrm{k}$ is potentially involved in $1 / 2(\mathrm{~N}-1)(\mathrm{N}-2)$ pairs of other companies: besides firm $\mathrm{k}$ there are $\mathrm{N}-1$ firms $\mathrm{i}$, and these have $\mathrm{N}-2$ contacts $\mathrm{j}$. The overall betweenness centrality of firm $\mathrm{k}, \mathrm{C}_{\mathrm{k}}$, equals $\frac{2}{(N-1)(N-2)} \sum_{i<j} C_{k}(i, j)$. Call $\mathrm{C}_{\mathrm{bmax}}$ the highest value of network betweenness of any firm in the network. Then betweenness centrality of the network is defined as follows: 


$$
C_{b}=\frac{1}{N-1} \sum_{k=1}^{N}\left(C_{b \max }-C_{k}\right)
$$

\section{Network density and the upper boundary of network centrality}

In this section we demonstrate a link between network density and degree centrality that is consistent with the proposition. Since the number of links $\mathrm{O}_{\mathrm{i}} \mathrm{L}_{\mathrm{i}}$ affects both the network density (in equation 1) and network centralization (through ${ }_{\mathrm{O}} \mathrm{C}_{\mathrm{i}}$ in equation 2), there is a relationship between the two indicators of network structure. Network centrality at a point in time is both a result of how many alliances (links) there are, and how they are distributed over the network participants. Combining equations (1) and (2) gives the following relationship between network density and network degree centrality:

$$
C_{d}=\frac{N}{N-2}\left(C_{d \max }-D\right)
$$

We can prove two aspects of the relationship between $D$ and $C_{d}$ in equation (4). Firstly, the slopes of the relationship between $\mathrm{D}$ and $\mathrm{C}_{\mathrm{d}}$ at the two extreme points of $(0,0)$ and $(0,1)$ are consistent with a hill-shaped relationship. The very first link formed in the network has a network density $D$ of $2 /(\mathrm{N}(\mathrm{N}-1))$, a $C_{\mathrm{dmax}}$ of $1 /(\mathrm{N}-1)$, and a network centrality $C_{d}$ of $1 /(\mathrm{N}-1)$. The slope of the incline at the origin $(0,0)$ is thus $N / 2$. The negative slope of the curve at the point $(1,0)$ can also be determined. Imagine that all potential links are formed but one. Hence, the total number of links is $\mathrm{N}(\mathrm{N}-1)-2$. Network density $\mathrm{D}$ is $(\mathrm{N}(\mathrm{N}-1)-2) /(\mathrm{N}(\mathrm{N}-1))$. There will be two firms that are linked to all N-2 other firms, but not to each other. They have N-2 links. All other firms have N-1 links. Thus, $C_{d m a x}$ is 1 . Using equation (4), this gives $C_{d}=2 /((\mathrm{N}-1)(\mathrm{N}-2))$. The negative slope of the curve is $(0-\mathrm{C}) /(1-\mathrm{D})$, which gives $-\mathrm{N} /(\mathrm{N}-2)$. This is in absolute terms a smaller slope than at the origin (N/2), if $\mathrm{N}$ exceeds four. Hence, we know that for a network size of five or larger, the hillshaped relationship between network centralization and network density is not symmetrical.

Secondly, equation (4) implies the following upper bound to degree centrality for a given level of network density:

$$
\mathrm{C}_{\mathrm{d}}^{\text {up }}=\left\{\begin{array}{l}
\frac{N}{2} D, \text { if } 0 \leq D \leq \frac{2}{N}, \text { and } \\
\frac{N}{N-2}(1-D), \text { if } \frac{2}{N}<D \leq 1 .
\end{array}\right.
$$

The explanation for this upper bound is as follows. Imagine we increase network density one link at a time. At each step, we allocate the link to firms such as to maximize network centrality. This consists of giving all links to one central firm until it is linked to every other firm. Its partner is each time another firm, to keep their number of links low. At a low number of links, the central firm is linked to as many partner firms as there are unique links. If there are $h$ unique links, this means that $\mathrm{L}_{\max }=\mathrm{h}, \mathrm{C}_{\mathrm{dmax}}=\mathrm{h} /(\mathrm{N}-1), \mathrm{D}=2 \mathrm{~h} /\left((\mathrm{N}(\mathrm{N}-1))\right.$, and $\mathrm{C}_{\mathrm{d}}=\mathrm{h} /(\mathrm{N}-1)$. This upward sloping curve increases up to the point that the central firm is linked to all other firms: $h=N-1, C_{d m a x}=1$, $\mathrm{D}=2 / \mathrm{N}$, and $\mathrm{C}_{\mathrm{d}}=1$. Any further increase in the number of links has no effect on $\mathrm{C}_{\mathrm{dmax}}$, while it increases $\mathrm{D}$, and thus decreases $\mathrm{C}_{\mathrm{d}}$ as a linear function in $\mathrm{D}$.

We note that the lower bound to network centrality is either zero or 'near' zero. By rearranging network links, the difference between individual firms' degree centralities can always 
be reduced to at least zero (for a symmetric network) and at most $1 /(\mathrm{N}-1)$. Insert this in equation (2) to see that the lower bound to $\mathrm{C}_{\mathrm{d}}$ is at most $1 /(\mathrm{N}-2)$.

Both the theoretical upper bound and the inclines of the actual curve at the two extreme points are consistent with a hill-shaped relationship in the proposition. The next section presents a simulation model to explore these links between alliance formation and network structure.

\section{A stochastic process leads to a hill-shaped relationship}

The formation of links between nodes in a network is partly a chance process. The chance aspect of link formation implies that some firms will accumulate more links than others. This accounts for some degree of network centrality. We present a simulation that shows that this argument offers support for the proposition.

A frequency distribution based on a chance process may have a specific form called the Power Law (Riccaboni \& Pammolli, 2002). Applied to firms and their ties, the power law states that when $n_{k}$ is the share of firms that have $\mathrm{k}$ or more ties, that $\mathrm{n}_{\mathrm{k}}=\alpha \mathrm{k}^{-\gamma}$, with $\alpha$ and $\gamma$ positive parameters specific to an industry or country. Riccaboni and Pammolli (2002) show that for alliances in the life sciences and in the information and communication technology industries, the actual distribution differs somewhat from the one predicted by the power law. The number of firms that have $\mathrm{k}$ or more ties (alliances), for about ten or more alliances, is actually larger than predicted by the power law. Still, the point is made that a chance process devoid of specific economic content will already lead to some firms having more alliances than others. A certain amount of network centrality emerges due to chance. This implication we intend to show here.

In a pure chance model there is a given chance a that any link between firms $(i, j)$ is formed. For a given alliance formation chance á and population $\mathrm{N}$, the chance $\mathrm{P}(\mathrm{k})$ that a firm forms $k$ links (in between 0 and $N-1$ ) is $\left(\begin{array}{c}N-1 \\ k\end{array}\right) \alpha^{k}(1-\alpha)^{N-1-k}$. The expected share of firms that have $\mathrm{k}$ links or more, $n_{k}$, is identical to $\mathrm{P}\left(\mathrm{L}_{\mathrm{i}}>=\mathrm{k}\right)$, which equals $1-\mathrm{P}\left(\mathrm{L}_{\mathrm{i}}<=\mathrm{k}-1\right)$. The chance that a firm has $\mathrm{k}-1$ links or fewer, $\mathrm{P}\left(\mathrm{L}_{\mathrm{i}}<=\mathrm{k}-1\right)$, equals $\sum_{j=0}^{k-1} P(j)$. Hence, $\mathrm{n}_{\mathrm{k}}$ is $1-\sum_{j=0}^{k-1}\left(\begin{array}{c}N-1 \\ j\end{array}\right) \alpha^{j}(1-\alpha)^{N-1-j}$. While $\mathrm{n}_{\mathrm{k}}$ is a decreasing function in $\mathrm{k}$, its fit with the power law $\left(\mathrm{n}_{\mathrm{k}}=\alpha \mathrm{k}^{-\gamma}\right)$ isn't quite good. ${ }^{1}$

The expected degree centrality $E\left(C_{D}\right)$ is a function of the expected network density $E(D)$. The expected density $E(D)$ equals the given link formation chance $\alpha$. The chance that all $\mathrm{N}$ firms have $\mathrm{j}$ links or fewer is $P\left(L_{i} \leq j\right)^{N}$. The chance that the maximum links in a network is $\mathrm{j}$ (in between 0 and $\mathrm{N}-1)$ is $P\left(L_{i} \leq j\right)^{N}-P\left(L_{i} \leq j-1\right)^{N}$. The expected value of $\mathrm{C}_{\mathrm{dmax}}$ is the following expression:

(6) $E\left(C_{d \max }\right)=\frac{1}{N-1} \sum_{j=0}^{N-1} j\left(\left(\sum_{k=0}^{j}\left(\begin{array}{c}N-1 \\ k\end{array}\right) \alpha^{k}(1-\alpha)^{N-1-k}\right)^{N}-\left(\sum_{k=0}^{j-1}\left(\begin{array}{c}N-1 \\ k\end{array}\right) \alpha^{k}(1-\alpha)^{N-1-k}\right)^{N}\right)$

\footnotetext{
${ }^{1}$ We $\operatorname{ran} \ln (\mathrm{P}(\mathrm{L}>=\mathrm{k}))=\mathrm{a}_{0}+\mathrm{a}_{1} \ln (\mathrm{k})$, then regressed $\mathrm{e}^{\mathrm{a} 0+\mathrm{a} \ln (\mathrm{k})}$ on $\mathrm{P}(\mathrm{L}>=\mathrm{k})$ to find an adjusted $\mathrm{R}^{2}$ of 0.436 .
} 
With equation (4) the expected degree centrality $\mathrm{E}\left(\mathrm{C}_{\mathrm{d}}\right)$ is $\frac{N}{N-2}\left(E\left(C_{d \max }\right)-E(D)\right)$. If we substitute the expression in equation (6) for $\mathrm{E}\left(\mathrm{C}_{\mathrm{dmax}}\right)$ and $\mathrm{E}(\mathrm{D})$ for $\alpha$ in the expected degree centrality $E\left(C_{d}\right)$, we have a relationship of $E\left(C_{d}\right)$ as a function of $E(D)$ and the population size $N$. Figure 1 plots this function for several values of population size. It shows that the larger the population, the lower degree centrality tends to be, given the expected level of density.

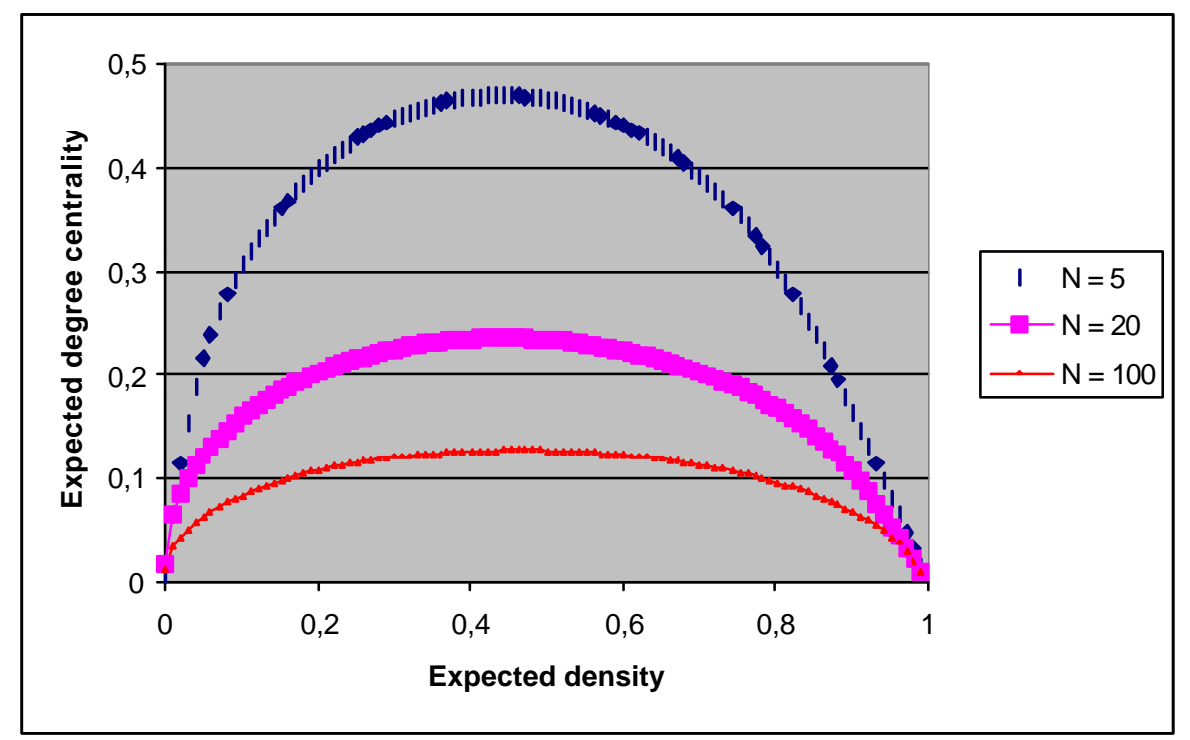

Figure 1: Expected degree centrality as a function of expected network density

We simulate the model for 20 and for 100 companies. There is a given chance á that any link between firms ( $i, j$ ) is formed. We run 999 simulations, in increasing size of á from 1/1000 to 999/1000. For each simulation, we calculate the network density and network centrality. This gives 999 pairs per simulation. Using these outputs, we run a regression of network centrality on network density. Figure 2 plots the degree centrality $C_{d}$ and the upper bound $C_{d}^{\text {up }}$ (equation 5) against network density, simulated for a population size of 20 . For each level of network density there is considerable variation in the network degree centrality. It illustrates the hill-shaped relationship. 


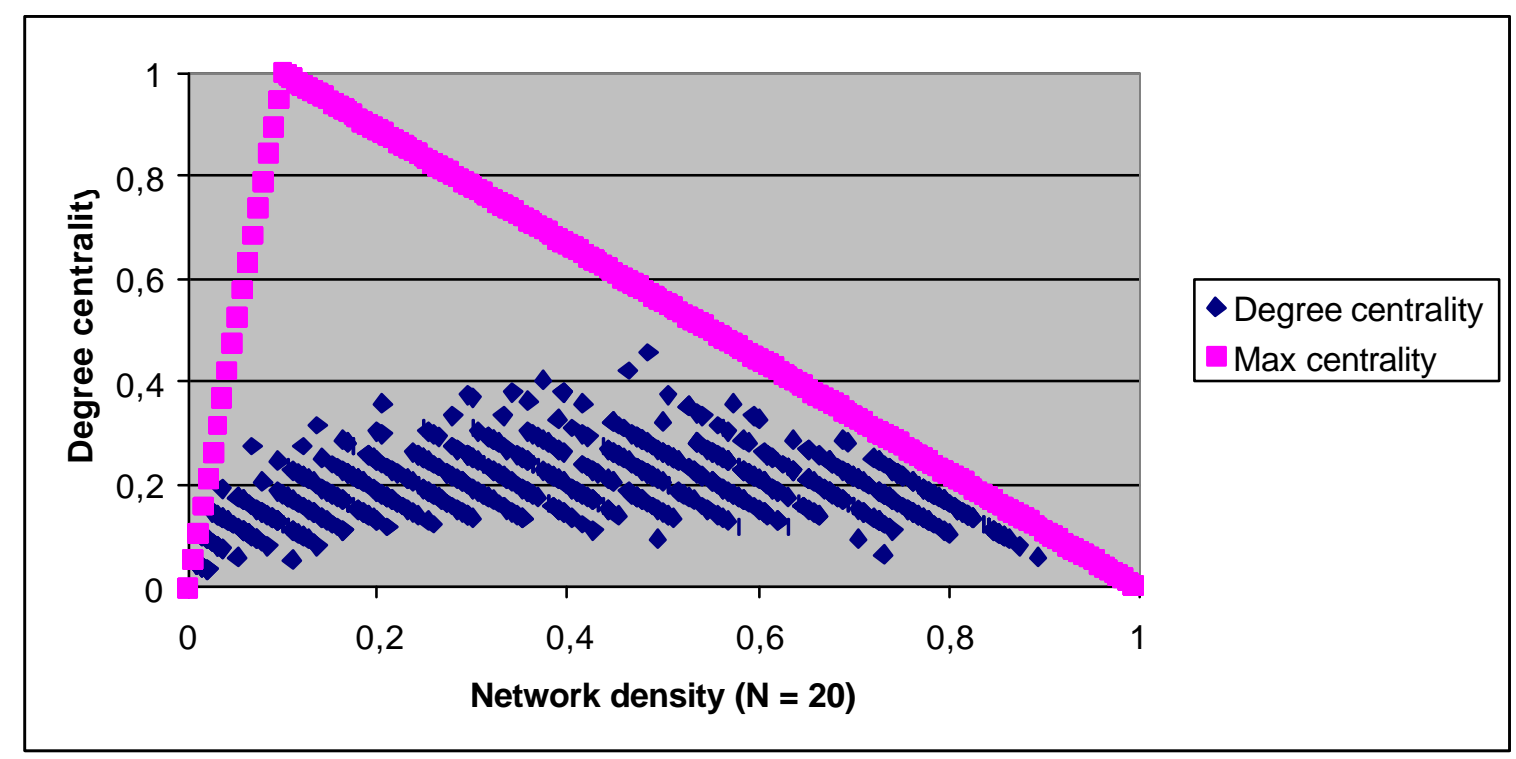

Figure 2: simulation of the degree centrality and network density $(\mathrm{N}=20)$

Table 1 shows the results of the regression analysis. We know from section 3 that the hill-shape will not be symmetric between $(0,0)$ and $(1,0)$. To approximate that, we use a beta-distribution. That is, we test for $C_{i}=D^{\alpha-1}(1-D)^{\beta-1}(i=b, d)$. This gives regressions $\ln C_{i}=a_{0}+a_{1} \ln D+a_{2} \ln (1-$ D). We have two runs of simulations, one for $\mathrm{N}=20$ and one for $\mathrm{N}=100$. We report the adjusted $\mathrm{R}^{2}$ for the regression of $\operatorname{Exp}\left(\mathrm{a}_{0}+\mathrm{a}_{1} \ln \mathrm{D}+\mathrm{a}_{2} \ln (1-\mathrm{D})\right)$ on $\mathrm{C}_{\mathrm{i}}$. We also have a simulation where $\mathrm{N}$ is randomly drawn from the uniform distribution on [5, 100]. This adds the network size (population) as another determinant of network centrality.

\begin{tabular}{|c|c|c|c|c|c|c|}
\hline & \multicolumn{2}{|l|}{$\mathrm{N}=20$} & \multicolumn{2}{|l|}{$\mathrm{N}=100$} & \multicolumn{2}{|c|}{$\begin{array}{l}\mathrm{N} \text { random between } 5 \text { and } \\
100\end{array}$} \\
\hline & $\begin{array}{l}\text { Degree } \\
\text { centrality }\end{array}$ & $\begin{array}{l}\text { Betweenness } \\
\text { centrality }\end{array}$ & $\begin{array}{l}\text { Degree } \\
\text { centrality }\end{array}$ & $\begin{array}{l}\text { Betweenness } \\
\text { centrality }\end{array}$ & $\begin{array}{l}\text { Degree } \\
\text { centrality }\end{array}$ & $\begin{array}{l}\text { Betweenness } \\
\text { centrality }\end{array}$ \\
\hline $\begin{array}{l}\text { Constant } \\
\left(\mathrm{a}_{0}\right)\end{array}$ & $\begin{array}{l}-0.572^{a} \\
(0.025)\end{array}$ & $\begin{array}{l}-1.432 \\
(0.035)\end{array}$ & $\begin{array}{l}-1.217^{\mathrm{a}} \\
(0.016)\end{array}$ & $\begin{array}{l}-4.065^{a} \\
(0.033)\end{array}$ & $\begin{array}{l}-0.434^{\mathrm{a}} \\
(0.027)\end{array}$ & \begin{tabular}{|l}
$-1.177^{\mathrm{a}}$ \\
$(0.054)$
\end{tabular} \\
\hline $\mathrm{N}$ & - & - & - & - & $\begin{array}{l}-0.0080^{a} \\
(0.0003)\end{array}$ & $\begin{array}{l}-0.0287^{\mathrm{a}} \\
(0.0006)\end{array}$ \\
\hline $\ln D\left(a_{1}\right)$ & $\begin{array}{l}0.531^{\mathrm{a}} \\
(0.014)\end{array}$ & $\begin{array}{l}0.770^{a} \\
(0.020)\end{array}$ & $\begin{array}{l}0.508^{a} \\
(0.008)\end{array}$ & $\begin{array}{l}0.281^{\mathrm{a}} \\
(0.017)\end{array}$ & $\begin{array}{l}0.550^{a} \\
(0.012)\end{array}$ & $\begin{array}{l}0.534^{\mathrm{a}} \\
(0.024)\end{array}$ \\
\hline $\begin{array}{l}\ln (1-D) \\
\left(a_{2}\right) \\
\text { Adj. } R^{2}\end{array}$ & $\begin{array}{l}0.773^{a} \\
(0.012) \\
0.556\end{array}$ & $\begin{array}{l}1.209^{a} \\
(0.017) \\
0.563\end{array}$ & $\begin{array}{l}0.670^{a} \\
(0.008) \\
0.728\end{array}$ & $\begin{array}{l}1.030^{a} \\
(0.018) \\
0.622\end{array}$ & $\begin{array}{l}0.724^{a} \\
(0.011) \\
0.617\end{array}$ & \begin{tabular}{|l}
$1.125^{a}$ \\
$(0.023)$ \\
0.502
\end{tabular} \\
\hline
\end{tabular}

With $\mathrm{a}_{1}>0$ and $\mathrm{a}_{2}>0$, the beta distribution gives a hill-shape, which is asymmetric since $\mathrm{a}_{1}<\mathrm{a}_{2}{ }^{2}{ }^{2}$ When the population size is variable, the population size has a significant negative impact on both

\footnotetext{
${ }^{2}$ The difference between the $\mathrm{a}_{1}$ and $\mathrm{a}_{2}$ is significant in all cases. When forcing identical parameters by taking $\ln (\mathrm{D})+\ln (1-\mathrm{D})$ as independent variable, the resulting adjusted $\mathrm{R}^{2}$ are less than in table 1 , resp., 0.500 , $0.305,0.696,0.017,0.324$, and 0.047 .
} 
degree centrality and betweenness centrality. This supports the intuition from figure 1 . The results on degree centrality and betweenness centrality differ somewhat in table 1 . The correlation between both centrality measures is $82.6 \%$ for the case where $\mathrm{N}$ varies between 5 and 100 .

\section{Discussion and conclusion}

This note has shown that three different indicators (statistics) of network structure are inherently linked. The economic relevance of a network indicator such as, notably, network centrality, raises the question what determines how centralized a network is? This paper presents a parsimonious explanation of network centrality that uses only data about the network itself.

The paper identifies two factors that have an influence on network centrality. It shows that network size and network density both indicate how centralized the network is. First, the network size has an impact. The larger the network size is, the smaller the degree centrality will be. The network size reduces the difference between the best-connected member and the unconnected population members, relative to the total number of contacts possible. The same holds for betweenness centrality. Population size reduces the ability of centrally connected firms to connect other, mutually unconnected, firms.

Secondly, the number of links that have been formed impact on network centrality. An increase in network density tends to make some firms better connected than others; hence centrality in the network increases. As the network density increases even further, more and more firms get better connected, and centrality decreases.

The argument in this note is contingent on how these indicators are measured. Different measurements lead to a differently specified relationship, as table 1 showed. While other indicators of network centrality exist, such as closeness centrality, we feel confident that the relationships found in this paper express a matter of substance.

We should be careful in interpreting what the simulation does and does not show. It does not argue that more than $50 \%$ of the variation in betweenness centrality or degree centrality depends on network density and network size (see table 1). These results may not carry over to real-life networks, as these may not have the same distribution of network sizes and network densities as our simulation. For example, the network densities in the pharmaceutical industry decreased from about $1 \%$ in the early 1980s to $0.15 \%$ in 1997 (Orsenigo, Pammolli, \& Riccaboni, 2001). In a study of the semiconductor industry, the mean network density was a mere 0.003 (Kogut et al., 1995). In these studies of broadly defined, large -scale industries, network densities of the levels included in this study, including ones close to unity, are not relevant. In studies of small-scale industrial networks, on the other hand, higher densities such as included in this study do occur (Bonaccorsi \& Giuri, 2001).

A strand in the literature on industry studies is the search for trends and stylized facts (Sutton, 1997). The literature that applies this approach to industry networks has looked at the power law (see references in Riccaboni \& Pammolli, 2002). The fit of our results with the power law is not quite good. The power law does not appear to be a reasonable benchmark for a pure chance process of alliance formation among companies. Nor does it appear $\mathfrak{b}$ describe real industries very well (Riccaboni \& Pammolli, 2002). There does not appear to be a theory behind the power law that would hold in the case of network structure. If we apply the kind of reasoning that Sutton (1997) uses to link formation and networks, we may be able to come up with stylised facts that do fit with insights on networking.

A direct empirical test of our argument will be a demanding endeavour. It is consistent with the hill-shaped relationship, for example, that for data with a small mean level of network density of 0.003, Kogut et al. (1995) found that there was a positive correlation between network centrality and network density of 0.591 . Note that table 1 would predict, for a network density of 0.003 , and $\mathrm{N}=20$, a slope of 0.695 of betweenness centrality and density. 
A cross-sectional test of our proposition needs data about different networks. In crosssectional terms, our argument is that differences in the size of these networks, and their density, have telling implications for the centrality in these networks.

In an inter-temporal perspective, our approach suggests that during the life cycle of an industry, its network centrality will change as the population size of the industry and the density of its networks will change. In a dynamic setting, it may be expected that network centrality affects firm performance, with feedback effects on network size and network density. This is surely a correct argument. This argument can be taken on board, to argue, for example, that changes in network size, by processes of entry and exit, and changes of network density, by the formation or dissolution of links, affect the centrality of the network.

The paper shows that a chance element in the alliance formation is enough to create network structure. Reallife economic processes will deviate from a pure chance process. In an empirical setting, the question becomes whether network centrality exceeds the level that would be expected from a chance process. If the formation of networks is subject to virtuous circles, as observed for example by Powell, Koput and Smith-Doerr (1996), network centrality will be higher than our simulation in this paper would suggest. A chance process may trigger some network centrality, which may feed on itself in an evolutionary process, to reach higher levels of network centrality. In common with Sutton's (1997) Bounds approach, the approach in this paper identifies lower and upper bounds on network centrality. Our approach can offer a starting point for an evolutionary theory of network structure by identifying the process hemmed in by these lower and upper bounds on network centrality.

\section{References}

Bonaccorsi, A., \& Giuri, P. (2001). Network structure and industrial dynamics: the long-term evolution of the aircraft-engine industry. Structural Change and Economic Dynamics, 12, 201-233.

Brass, D. J., Butterfield, K. D., \& Skaggs, B. C. (1998). Relationships and Unethical Behavior: A Social Network Perspective. Academy of Management Review, 23(1), 14-31.

Burt, R. S. (1997). The Contingent Value of Social Capital. Administrative Science Quarterly, 42, 339-365.

Hite, J. M., \& Hesterly, W. S. (2001). The evolution of firm networks: from emergence to early growth of the firm. Strategic Management Journal, 22, 275-286.

Kogut, B., Walker, G., \& Kim, D.-J. (1995). Cooperation and entry induction as an extension of technological rivalry. Research Policy, 24, 77-95.

Madhavan, R., Koka, B. R., \& Prescott, J. E. (1998). Networks in transition: how industry events (re)shape interfirm relations. Strategic Management Journal, 19, 439-459.

Orsenigo, L., Pammolli, F., \& Riccaboni, M. (2001). Technological change and network dynamics: Lessons from the pharmaceutical industry. Research Policy, 30, 485-508.

Powell, W. W., Koput, K. W., \& Smith-Doerr, L. (1996). Interorganizational collaboration and the locus of innovation: networks of learning in biotechnology. Administrative Science Quarterly, 41, 116-145.

Riccaboni, M., \& Pammolli, F. (2002). On firm growth in networks. Research Policy, 31, 14051416.

Sutton, J. (1997). Gibrat's Legacy. Journal of Economic Literature, 35(1), 40-59. 